Cumhuriyet International Journal of Education-CIJE

e-ISSN: 2147-1606

Vol 5 (1), 2016, $53-70$

\title{
Investigation of Occupational Anxieties of Preschool Teacher Candidates In Terms Of Some Demographic Features
}

\author{
Bahar GÜMRÜKÇÜ BİLGİCİ, Ümit DENİZ
}

Summary

\section{INTRODUCTION}

The personality and mental health of teachers are very important as they are reflected in the ways in which the students behave. Many studies on occupational anxiety of teacher candidates were conducted over years. The most frequently reported anxieties are about controlling the class and motivating pupils. The main purpose of this study is to investigate the occupational anxieties of preschool teacher candidates. This study tries to answer the following questions:

- Is there any impact of gender on the occupational anxieties of preschool teacher candidates?

- Is there any impact of age on the occupational anxieties of preschool teacher candidates?

- Is there any impact of preference of Preschool Teaching program on the occupational anxieties of preschool teacher candidates?

- Is there any impact of satisfaction with their preference of undergraduate program on the occupational anxieties of preschool teacher candidates?

\section{METHOD}

This is a descriptive research in which relational model is used to investigate the occupational anxieties of preschool teacher candidates. Research sample is constituted by 201 preschool teacher candidates who are studying at Kastamonu University, Faculty of Education, Department of Primary Education, and Division of Preschool Teaching. Occupational Anxiety Scale for the Preschool Teacher Candidates which was developed previously and Personal Information Form were used to collect data. The scale consists of 9 factors and 60 items. These 9 factors were named as task-related anxieties, pupil-related anxieties, colleague-related anxieties, employment-related anxieties, personal evolutionrelated anxieties, parent-related anxieties, school management-related anxieties, economic/social anxieties and adaption-related anxieties. The data was analyzed using descriptive analysis methods.

\section{FINDINGS}

According to data, male preschool teacher candidates have more task-related anxieties than males while female candidates have more employment-related anxieties than females. The candidates between 18-19 years old have more colleague-related anxieties, parent-related anxieties and total anxieties than other ages and these candidates have more economic/social anxieties than the candidates who are 20-21 years old. The preschool teacher candidates who had the preschool program on their university program selection list at $16^{\text {th }}$ place or higher have more task-related anxieties, personal evolution-related anxieties, school managementrelated anxieties, economic/social anxieties and total anxieties than those who prioritized it more. Finally, the candidates who are satisfied with their preference for the preschool program have less pupil-related anxieties and personal evolution-related anxieties than the others.

\section{SUGGESTIONS}

In consideration of the occupational anxieties of preschool teacher candidates, some studies which could reduce these can be carried out. This study was limited to teacher 
Cumhuriyet International Journal of Education-CIJE

e-ISSN: $2147-1606$

Vol 5 (1), 2016, 53 - 70

candidates from Kastamonu University. Applying the Occupational Anxiety Scale for the Preschool Teacher Candidates to preschool teacher candidates from several universities could provide a wider account of the issue. Improvements for teacher candidates can be discussed throughout the country according to the data which will be obtained. 